УДК 94:[37:001.895(477) «185/195»

DOI https://doi.org/10.31470/2518-7600-2021-11-186-204

PEDAGOGICAL INNOVATIONS BY KHRYSTYNA ALCHEVSKA IN THE PUBLIC SCHOOL SYSTEM OF THE SECOND HALF OF THE NINETEENTH - EARLY TWENTIES CENTURIES

\title{
ПЕДАГОГІЧНІ ІННОВАЦІЇ ХРИСТИНИ АЛЧЕВСЬКОЇ В СИСТЕМІ НАРОДНОГО ШКІЛЬНИЦТВА ДРУГОЇ ПОЛОВИНИ ХІХ - ПОЧАТКУ ХХ СТОЛІТТЯ
}

\section{ПЕДАГОГИЧЕСКИЕ ИННОВАЦИИ КРИСТИНЫ АЛЧЕВСКОЙ В СИСТЕМЕ НАРОДНОЙ ШКОЛЫ ВТОРОЙ ПОЛОВИНЫ ХІХ - НАЧАЛА ХХ ВЕКА}

\section{Людмила Хмельницька,} кандидат історичних наук,дочент кафедри історії $i$ культуриУкраӥни та специіальнихісторичних дисииплін ludmylahm@gmail.com https:// orcid.org/0000-00032482-4322 ДВНЗ «Переяслав-Хмельницький державнийпедагогічний університетімені Григорія Сковороди», вул. Сухомлинського, 30 , м. Переяслав, Київська обл., Україна, 08401
Liudmyla Khmelnytska, Ph.D. in Historical Sciences, Associate Professor at the Department of History and Culture of Ukraine and special historical disciplines ludmylahm@gmail.com https:// orcid.org/0000-0003-24824322SHEI «Pereiaslav-Khmelnytsky Hryhorii Skovoroda State Pedagogical University»Pereiaslav 30, Sukhomlynskoho St.Kyiv region, Ukraine 08400

\section{ABSTRACT}

The article highlights the life and creative path of Khrystyna Danylivna Alchevska, in particular, examines the main directions 
of her educational and pedagogical activities, as well as scientific and methodological achievements in the field of pedagogy and outstanding contribution to the development of Ukrainian culture.

It is noted that Khrystyna Alchevska was one of the first to raise the issue of universal free primary education, in particular educational establishments for women, when Sunday schools were banned. The Kharkiv Sunday School for Women, which had been in an illegal status for eight years, became such an institution.

According to the principles of versatile education and training Khrystyna Alchevska in the work of the Kharkiv Sunday school for Women introduced and promoted new innovative forms and methods of the educational process: discussions of what pupils had read, lessons in nature, developing lessons on writing, educational meetings, keeping a diary by teachers and so on.

Khrystyna Alchevska presented her pedagogical views and practical experience in numerous works. Among them: "Overthought and Survived: Diaries, Letters, Memoirs» (1912) [Peredumannoye i perezhitoye: dnevniki, pis'ma, vospominaniya» (1912)], «Half-century Jubilee» (1912) [Poluvekovoy yubiley(1912)] and others.

An integral part of Khrystyna Alchevska's educational activities is the consistent and purposeful popularisation of literature and reading culture in general. For this purpose, by laborious joint work with teachers and students an index of books for public and children reading "What is to be read by people? (1884-1906)[Chto chitat' narodu?] in three volumes was created. The publication was highly praised by L. Tolstoy, A. Chekhov, I. Franko, and L. Ukrainka.

The results of the pedagogical work and the educational and methodological innovations introduced by Khrystyna Alchevska were published several times in the form of annual reports containing detailed information about the school's problems.

One of the primary issues in the organization of the teaching and educational process for Khrystyna Alchevska was the selection of teaching staff, their use of best teaching practices in their work 
and their tendency for constant self-improvement. Among the teachers-pioneers of Khrystyna Alchevska's school was B. Hrynchenko, a prominent Ukrainian writer who taught at the zemstvo school, which had been founded by the Alchevskys, in the village of Oleksiivka in Katerynoslav region.

Khrystyna Danylivna Alchevska, as well as her entire family, greatly influenced the evolution of pedagogical thought and domestic culture, raising it to a high level of development.

Keywords: Khrystyna Alchevska, pedagogy, education, methodology, Sunday school, pedagogical activity, teaching experience, innovation.

Постановка проблеми. Починаючи 3 90-х років минулого століття невпинно зростає інтерес як суспільства так і окремих сегментів науково-дослідної галузі до вивчення та подальшої інтеграції в сучасні освітні процеси педагогічних інновацій попередніх століть. 3 огляду на це, дослідження гендерного аспекту в педагогічній спадщині визнаних корифеїв $\epsilon$ актуальною складовою сучасних педагогічних та суспільноісторичних досліджень. Активна педагогічна та просвітницька діяльність Христини Алчевської, що є прикладом у напрямку становлення та популяризації безкоштовної жіночої освіти у межах приватного шкільництва не втрачає своєї актуальності і в умовах побудови нової української школи.

Аналіз останніх досліджень і публікацій. Представленій проблемі в тій чи іншій мірі стали в нагоді праці Х.Д. Алчевської (Алчевська, 1912, 1881, 1889, 1990), В.Д. Бардіанової (Бардіанова, 2002), Л. Бондар (Бондар, 2005, 2006), Е. Вахтерової (Вахтерова, 1912), Іващенко В., Палійчук Р. (Іващенко\&Палійчук, 2014) та ін.

Мета розвідки: 3 позиції сучасної історичної науки дослідити життєвий та творчий шлях Христини Алчевської, основні інновації педагогічної та просвітницької діяльності, показати їі внесок у становлення та розвиток педагогічної науки минулого та сучасності. 
Виклад основного матеріалу. Христина Данилівна Алчевська (Журавльова) - педагог-просвітитель, фундаторка першої в Україні безкоштовної жіночої недільної школи, основоположниця методики навчання грамоти дорослих, яскрава представниця української інтелігенції середини XIX початку XX ст., діяльність якої неоднозначно оцінюється i сьогодні (Іващенко\&Палійчук, 2014:39).

Народилася 16 квітня 1841 р. у містечку Борзна на Чернігівщині у родині батька українця, викладача повітового училища та матері румунки - випускниці Смольного інституту. Виховуючись в інтелігентній родині, Христина Алчевська згодом буде згадувати, що саме мати володіла здібністю «привертати серця людей» (Бондар, 2005: 59). 3 раннього дитинства дівчина мала тісний контакт з народом, особливо переїхавши до Курська, куди батька відправили на роботу, спілкуючись з годувальницею на ім'я Гапка та місцевими кріпаками, які стали іiі першими учнями (Іващенко \& Палійчук, 2014:39).

Шлях до здобуття освіти Христиною був складний, адже батько був противником жіночої освіти. 3 цього приводу $\mathrm{X}$. Алчевська в праці «Передумане й пережите» буде згадувати, як отримувала знання потай від батька, підслуховуючи приватні уроки, що надавались двом іiі братам і навчилась читати і писати раніше їх (Алчевська, 1912: 21). В ранньому дитинстві X. Алчевська сформувала в себе любов до читання, ознайомившись з усією наявною в батьківській бібліотеці літературою. Самоосвіта дала можливість отримати грунтовні знання та свідоме бажання «Навчити якомога більше жінок грамоті». Це кредо стало метою життя Х. Алчевської, що сама так і не отримала систематичної освіти (Алчевська, 1912: 22).

Трагічні події особистого життя змінять характер дівчини. В 16 років, втративши матір, Христина Данилівна знайде порятунок у викладацькій діяльності. Так, маєток знайомих Мамчич під Курськом стане зі слів самої майбутньої фундаторки жіночої школи «першим знайомством з народом і 
школою» (Алчевська, 1912: 29). Христина стане небайдужим учасником суспільних процесів в державі, поборницею за права жінок, про що свідчить численне листування з прогресивними діячами того часу. Показовим прикладом є листування 1859 р. з О. Герценим під псевдонімом «Українка» та популяризація його творчості. Один з таких листів було надруковано в журналі «Колокол» за сприяння М. Драгоманова та I. Франка де Христина у властивій для неї радикальній манері закликала будити громадську свідомість жінок (Бондар, 2006: 65).

Зацікавленість радикальними ідеями спонукатиме X. Алчевську вступити до гуртка радикально налаштованої молоді, де окрім читання прогресивної літератури будуть займатися поширенням заборонених творів та «багато читати, дискутувати, говорити про народ, про роботу для народу» (Вахтерова, 1912:6).

Визначальним роком в житті та майбутній професійній діяльності став 1862 р. - рік, коли Христина Данилівна вийшла заміж за О.К. Алчевського - власника Торгового і Земельного банків та переїхала до м. Харкова (Бондар, 2006:66). Чоловік окрім інвестицій у великі підприємства багато уваги приділяв громадській діяльності: в 1860-ті роки був очільником Харківської громади, опікувався просвітою, брав участь в організації безкоштовних шкіл, видавництві дешевої книжки українською мовою, організації шевченківських вечорів, зустрічей з театральними трупами, влаштовуванні концертів тощо. Христина Данилівна в Харкові стала єдиною жінкою членом місцевого гуртка «Громади», яким керував їі чоловік (Алчевська, 1912: 13).

1860-ті роки стали періодом загострення питання, щодо поширення народної освіти та ініціювання з боку передової інтелігенції відкриття безкоштовних недільних шкіл, які проіснували лише до середини 1862 р. (Вахтерова, 1912:9). 10 червня 1862 р. Х.Д. Алчевська відкрила Харківську приватну жіночу недільну школу, що проіснувала протягом восьми років, незважаючи на нелегальний статус в зв'язку з відсутністю у 
Христини Данилівни диплому про вищу освіту (Вахтерова, 1912:10).

У власному будинку, вечорами Х. Алчевська самостійно проводила заняття з ученицями, розділеними на групи по 1012 осіб, адже інші вчителі не наважувались викладати у нелегальній школі (Вахтерова, 1912: 1-12).

Питання надання школі легального статусу не покидало iii фундаторку протягом восьми років. 3 огляду на це $\mathrm{X}$. Алчевська склала іспит з російської мови, арифметики і Закону Божого та отримала диплом і право на викладання. Згодом, згадувала: «Думка, що від кожного мого слова залежить «бути чи не бути» школі, якось боляче тиснула на мене...» (Вахтерова, 1912: 14).

Офіційне відкриття школи у будівлі Першого повітового училища відбулося 22 березня 1870 р., що підтверджує лист голови Харківського міського відділу внутрішніх справ до штатного доглядача повітових училищ (Бондар, 2006:67). Незабаром, Х.Д. Алчевська стала попечителем створеного закладу. Майже 60 років своєї діяльності Харківська жіноча недільна школа була передовою педагогічною установою для дорослого населення не лише в Україні, а й у межах всієї Російській імперії (Іващенко\&Палійчук, 2014: 39-40).

Власне приміщення, побудоване на кошти О. Алчевського, за проектом видатного архітектора О. Бекетова у Мироносицькому провулку - нині вул. Жон Мироносиць, б. 9. школа отримала лише 1896 р. Будинок вартістю 50 тис. руб. єдине власне приміщення серед усіх недільних шкіл Російської імперії (Мухін, 1979:53). 3 цього приводу Х. Алчевська згадувала: «Це єдина недільна школа, яка розташована у власному будинку. Розміри будівлі дали можливість значно збільшити набір учениць, зручно розмістити класи, шкільний музей і дві бібліотеки. Для вчителів і учнів» (Алчевська, 1912: 17-18).

Лише протягом 1896 р. за таких комфортних умов навчання в школі нараховувалось близько 100 учениць та 
працювало 22 викладачі. Ще до початку навчального процесу учениць ділили на групи, за рівнем підготовки: вмінням читати, писати, володінням елементарними навиками арифметики тощо. Брався до уваги й віковий ценз(Мухін, 1979: 54). Відповідно були виділені наступні вікові групи: малолітні (1012 років), підлітки (13-15 років), дорослі (від 16 років). За рівнем підготовки: неписьменні, напівписьменні (лише читати по складам), малописьменні, письменні. В школі учні отримували елементарні відомості 3 історії, фізики, хімії, арифметики, географії, історії культури, гігієни, анатомії, фізіології, тобто знання такого рівня, які б могли знадобиться в реальному повсякденному житті (Мухін, 1979: 55-56).

Школа проіснувала до 1919 р. Христина Данилівна головувала колективом педагогів - сподвижників. Безоплатно викладали понад 100 вчителів. Серед них - світила вітчизняної науки Д. І. Багалій, Б. Я. Данилевський (Мухін, 1979: 57-58).

Унікальним явищем у діяльності Харківської приватної жіночої недільної школи став музей наочних посібників (таблиць, картин, альбомів, історичних та географічних карт, манекенів, чучел тощо) - єдиний у своєму роді, якого не мала жодна початкова школа Російської імперії. На 1896 р. згаданий музей налічував 434 експонати, причому, були посібники, спеціально виготовлені для цього музею (Мухін, 1979: 60).

Вся система навчання та виховання у Харківській недільній школі для жінок регламентувалась «Статутом попечительського комітету Харківської недільної школи» та сприяла не лише грунтовному засвоєнню предметів, але й швидкому адаптуванню учениць до нового середовища (Мухін, 1979:62). Визначальними принципами навчання та виховання стали принципи гуманізму, демократизму, народності та гуманності. Повага до прав особистості, сприяння вільному розвитку моральних та духовних потреб жінки були основними орієнтирами у навчально-виховному процесі закладу і тим самим сприяли залученню нових учнів (Бардіанова, 2002: 112). 
Особливу увагу X. Алчевська приділяла питанню підбору викладацьких кадрів, де визначальним фактором завжди був професіоналізм та бажання до самовдосконалення (Бардіанова, 2002: 113-114). Так, за п'ятдесят років педагогічної діяльності в школі викладало понад тисячу педагогів. 1870 i 1871 pp. недільну школу відвідав видатний педагог-методист М. Корф, задля того, щоб на власні очі переконатись чи школа дійсно існує чи лише на папері, та які результати від такого новаторського навчання (Корф, 1843: 110).

Результати своєї інспекції М. Корф виклав на сторінках праці «Наше школьное дело», де зазначив: «Харківська недільна школа зробила великий крок уперед: із школи грамотності перетворилась у повну елементарну школу, яку варто відвідати кожному, хто хоче бачити на ділі застосування кращих методів навчання з усіх предметів елементарного курсу» (Корф, 1843: 137, 138).

Однією 3 показових педагогічних інновацій, запроваджених в школі X. Алчевської був той факт, що всі організаційні та методичні питання в роботі закладу (форми і методи навчання, методика проведення предметних уроків, ознайомлення $з$ педагогічними й методичними інноваціями тощо) вирішувалися на щотижневих педагогічних зборах у ході відкритих дебатів (Мазуркевич, 1988: 256).

За ініціативи самої Х. Алчевської вчителі недільної школи вели свої педагогічні щоденники, які потім зачитували на педагогічних зборах. Дослідження цих щоденників дає підставу сьогодні стверджувати, що вони слугували не лише засобом самоконтролю та самоорганізації вчителів, але й сприяли систематичному психолого-педагогічному спостереженню за ученицями, вивченню психоемоційної атмосфери в учнівському колективі, рівню адаптації в школі. Щоденник на думку самої $\mathrm{X}$. Алчевської мав слугувати засобом для обміну педагогічним досвідом та методичною підтримкою молодих вчителів (Мазуркевич, 1988: 257-258). 
Сама Х. Алчевська значну увагу приділяла публікуванню так званих річних звітів, що містили детальну інформацію про проблеми школи, з якими стикались вчителі, щоденне життя, цікаві випадки з навчального процесу тощо. Саме такі звіти та щоденники, на думку X. Алчевської, мали ініціювати новаторство в навчально-виховному процесі, спонукати вчителів до проведення порівняльного аналізу та оцінки своєї педагогічної діяльності.

Недільна школа для жінок у Харкові не єдине дітище Х. Алчевської. Так, 1879 р. власним коштом педагог відкрила однокласну земську школу в с. Олексіївка на Катеринославщині пояснюючи це тим, що: «я бажала відкрити не приватну школу, а земську, були такі: мене може не бути, між тим, земство, як представник місцевої інтелігенції, підтримає навчальний заклад» (Алчевська, 1881:19-20). Навчальний процес в олексіївській школі проходив російською мовою, яка була складною для розуміння простих українських дітей. Досвід роботи в даному навчальному закладі X. Алчевська виклала на сторінках своєї праці «История открытия школы в деревне Алексеевка Михайловской волости» (1881), (Алчевська:1881) яка сьогодні зберігається у фонді ДНПБ України ім. В.О. Сухомлинського (Іващенко\&Палійчук, 2014: 41).

Найбільшою заслугою школи в Олексіївці були педагогічні кадри, серед яких видатний український письменник Борис Грінченко, що шість років віддав вчителюванню в земській школі (1887 - 1893 рр.) (Алчевська, 1881:12). Виходячи 3 тогочасних реалій, Б. Грінченко був змушений ознайомлювати учнів з українською мовою таємно «... хоч і не вкраїнська була школа в Олексіївні, та все ж, отримавши освіту, школярі в ній знали, що вони українці, знали історію i географію України, знали про всіх видатних письменників і про їх писання, знали про тяжке становище України, знали про Галичину, запевне більше, ніж тодішній пересічний українець-інтелегент, і свої знання уміли 
висловлювати путящою українською мовою» (Алчевська, 1881:13).

Поважаючи Б. Грінченка, Х. Алчевська все ж не поділяла його погляди на методи та форми організації діяльності школи. Так, у період переслідування українського руху Х. Алчевська, задля збереження закладу вирішила не чинити опору i спрямувала роботу школи легально, з російською викладовою мовою (Бардіанова, 2002: 116).

Важливим засобом виховання молоді в дусі національнодемократичних ідей Х.Д. Алчевська вважала матеріали народної педагогіки, твори українських письменників і поетів, які розкривали особливості багатогранної національної культури народу, загальнолюдські цінності та ідеали, шляхи боротьби за національне визволення (Бардіанова, 2002:116117). У своєму навчальному закладі, незважаючи на заборону, $\mathrm{X}$. Алчевська популяризувала використання української мови та великого значення надавала позакласному читанню.

3 цією метою при Харківській недільній жіночій школі 3 ініціативи Х. Алчевської було створено бібліотеку, що вражала різноманіттям книжкового фонду, який мав прислужитись як учням так і вчителям та розроблено правила користування книгозбірнею. Згідно правил визначалась придатність книги для читання, іiі переваги та недоліки, а працівники бібліотеки були зобов'язані проводити бесіди з читачами (Бардіанова, 2002: 118). Саме ці відомості про книги, що в обов’язковому порядку занотовувалися вчителями та бібліотекарями Харківської недільної школи та стали підгрунтям для створення $\mathrm{X}$. Алчевською методико-бібліографічного порадника книг для читання народу і зокрема, дітей «Что читать народу?» (18841906) у трьох томах (Іващенко\&Палійчук, 2014: 41).

Спеціальний розділ порадника був присвячений творам видатних українських письменників і поетів. До нього увійшли також триста найкращих пісень. У підготовці порадника брала участь i донька педагога, учителька-поетеса Христина Олексіївна Алчевська (Іващенко\&Палійчук, 2014: 41-42). 
Знаковою постаттю в українській культурі та літературі для Х. Алчевської був Т. Шевченко. 3 ранньої юності і протягом всього життя педагог пронесла любов до творчості Кобзаря, використовуючи його спадщину для навчання читання та декламування віршів учениць своєї недільної школи (Бардіанова, 2002:121). На подвір'ї їі садиби 1889 р. було встановлено перше у світі погруддя Т. Шевченка, а друге Харківське повітове міське училище, попечителем якого була X. Алчевська, стало першим навчальним закладом у Росії, котрому було присвоєно ім'я великого поета. Не стояла осторонь X. Алчевська і від збору коштів на відкриття пам'ятника I. Котляревському у Полтаві (1903) (Бардіанова, 2002: 122).

Особливого значення у школі Х. Алчевська надавала літературним бесідам. Педагог розробляла питання методики проведення літературних бесід з різних предметів. Так, у Харківській жіночій недільній школі літературні бесіди стали обов'язковою складовою змісту предметів, бесіди проводилися у класі за чітко розробленою програмою, а не лише як форма позакласної роботи. Результати перевірялись письмовими роботами, що довало можливість вчителям об'єктивно оцінювати рівень знань учнів (Іващенко\&Палійчук, 2014: 41-42).

Показово, що в школі, створеній Х. Алчевською, багато уваги виховному процесу. Так, традиційними стали шкільні свята (урочистості 3 нагоди ювілейних дат народження письменників, новорічні та українські народні свята). Проводилися екскурсії на природу (Іващенко\&Палійчук, 2014: 41-42).

У науково-методичній роботі вчителі Харківської жіночої недільної школи використовували досвід відомих діячів вітчизняної педагогічної думки: М.Ф. Бунакова, В.І. Водовозова, В.П. Вахтерова, М.О. Корфа, К.Д.Ушинського та інших. Так, дослідник педагогічної спадщини Х. Алчевської M.I. Мухін у праці «Педагогічні погляди і освітня діяльність 
Х.Д. Алчевської» (1979) відзначав цінний досвід організації та проведення педагогічних виставок, що слугували, на його думку, засобом популяризації і пропаганди діяльності недільних шкіл (Мухін, 1979: 79-80).

Важливим $є$ й той факт, що ще за життя здобутки Х. Алчевської були визнані на міжнародному рівні. Так, Харківська жіноча недільна школа була представлена на всесвітніх форумах у Москві та Нижньому Новгороді (1895, 1896), Антверпенській, Брюссельській, Чиказькій i двох Паризьких $(1889,1900)$ міжнародних виставках, де була здійснена демонстрація карт, наочних посібників, фотографій та діаграм, численних матеріалів, що характеризували навчальний процес та роботу шкільної бібліотеки (Іващенко\&Палійчук, 2014: 39).

За визначний внесок в розвиток педагогічної думки $\mathrm{X}$. Алчевська була обрана почесним членом багатьох освітніх товариств. Так, Московське і Петербурзьке економічні товариства представили іiі до нагороди золотими медалями. 1889 р. на міжнародному конгресі приватної ініціативи у справі народної освіти, що проходив у Франції Х. Алчевську було обрано віце-президентом Міжнародної ліги освіти. Радянський уряд теж високо оцінив сподвижницьку діяльність педагога, призначивши їй одній з перших персональну пенсію (Іващенко \& Палійчук, 2014: 42).

Не лише Христина Данилівна, але i вся родина Алчевських залишила помітний слід Таким чином, та важливий внесок в історії української культури. Так, син Іван став знаменитим на весь світ тенором, гастролював у Росії та Франції (Мухін, 1979: 167). Під час приїзду до Харкова радо співав на шкільних вечорах. Син Микола став присяжним повіреним, організовував освітні заклади для дорослих, працював учителем початкових класів, а за радянських часів Микола Алчевський - видатний педагог та автор першого українського радянського букваря. Син Григорій став композитором та вокальним педагогом. Донька Христя 
цікавилася педагогікою і поезією (Мухін, 1979: 168). Померла Христина Данилівна Алчевська 15 серпня 1920 р. Була похована в сімейному склепі на міському кладовищі м. Харкова (Мухін, 1979: 173).

Висновки та перспективи подальших розвідок у даному напрямку. Таким чином, педагогічні інновації Христини Данилівни Алчевської значною мірою прислужились вітчизняній педагогічній науці, збагативши ії новими методами та формами організації навчально-виховної діяльності, що своїм корінням сягали традицій національного виховання та популяризації національної культури. I на сьогодні спадщина X. Алчевської не вивчена достатньо грунтовно, а тому дана тема має всі перспективи подальшого дослідження.

\section{ДЖЕРЕЛА ТА ЛІТЕРАТУРА}

1. Алчевская Х. Д. Передуманное и пережитое: дневники, письма, воспоминания. Москва: Типография И. Д. Сытина, 1912. $466 \mathrm{c}$.

2. Алчевская X. История открытия школы в деревне Алексеевке Михайловской волости. Харьков: Типографія М. Зильберберга, 1881. 48 с

3. Алчевская Х.Д. Что читать народу? Критический указатель книг для народного и детского чтения. СПб. Т. 1. 1888; Т. 2. 1889; Т. 3. 1906.

4. Алчевская Христина Даниловна. Полувековой юбилей (1862-1912). Москва: Типография И. Д. Сытина, 1912. 244 с.

5. Алчевська Х.Д. Твори [Текст]. Київ: Дніпро, 1990. 558c.

6. Бардіанова В.Д. 20 видатних українських педагогів / За ред. А.М. Бойко.Полтава: АСМI, 2002. 455 с.

7. Бондар Л. Алчевська Христина Данилівна. Українська педагогіка в персоналіях: У 2 кн.: Навч. посібник / За ред. О.В. Сухомлинської. Київ: Вища школа, 2005. 537 с.

8. Бондар Л. Педагогічна діяльність Христини Алчевської в контексті руху за освіту дорослих (До 165-річчя від дня народження). Історико-педагогічний альманах. 2006. Вип. 2. C. 65-72. 
9. Вахтерова Э. Пятьдесят лет работы для народа: (к пятидесятилетнему юбилею Х. Д. Алчевской). Москва: тип. П. П. Рябушинского, 1912. 24 с.

10. Іващенко В., Палійчук Р. Педагогічна діяльність Христини Алчевської в документах із фонду Державної науково-педагогічної бібліотеки України імені В.О. Сухомлинського. Вісник книжкової палати. 2014. №7. C. 39-42.

11. Корф Н. А. Наше школьное дело: сборник статей по училищеведению. Москва: изд. Братьев Салаевых, 1873. 430 с.

12. Мазуркевич А.Р. Христина Даниловна Алчевская. Антология педагогической мысли Украинской СССР / Сост. Н.П.Калениченко. Москва: Педагогика, 1988. С. 255-258.

13. Мухін М.І. Педагогічні погляди і освітня діяльність Х.Д. Алчевської. Київ: Вища школа, 1979. 183 с.

\section{REFERENCES}

1. Alchevskaya, Kh. D. (1912). Peredumannoe i perezhitoe: dnevniki, pis'ma, vospominaniya [Overthought and Survived: Diaries, Letters, Memoirs]. Moskva: Tipografiya I. D. Sytina, 466 [in Russian].

2. Alchevskaya, Kh. (1881). Istoriya otkrytiya shkoly v derevne Alekseevke Mikhaylovskoy volosti [The story of the opening of a school in the village of Alekseevka, Mikhailovska Parish]. Khar'kov: Tipografiya M. Zil'berberga, 48 [in Russian].

3. Alchevskaya, Kh.D. (1888;1889). Chto chitat' narodu? Kriticheskiy ukazatel' knig dlya narodnogo i detskogo chteniya [What is to be read by the people? A critical index of books for public and children's reading.]. SPb. T. 1. 1888; T. 2. 1889; T. 3. 1906 [in Russian].

4. Alchevskaya Khristina Danilovna. Poluvekovoy yubiley (1862 - 1912) [Half-century jubilee (1862 - 1912)]. Moskva: Tipografiya I. D. Sytina, 1912, 244 [in Russian].

5. Alchevska, Kh.D. (1990). Tvory [The works]. Kyiv: Dnipro, 558 [in Ukraina]. 
6. Bardianova, V.D. (2002). 20 vydatnykh ukrainskykh pedahohiv [20 prominent Ukrainian educators]. / Za red. A.M. Boiko.Poltava: ASMI, 455 [in Ukraina].

7. Bondar, L. (2005). Alchevska Khrystyna Danylivna. Ukrainska pedahohika $v$ personaliiakh [Alchevska Khrystyna Danylivna. Ukrainian pedagogy in persons]: U 2 kn.: Navch. posibnyk / Za red. O.V. Sukhomlynskoi. Kyiv: Vyshcha shkola, 537 [in Ukraina].

8. Bondar, L. (2006). Pedahohichna diialnist Khrystyny Alchevskoi v konteksti rukhu za osvitu doroslykh (Do 165-richchia vid dnia narodzhennia) [The pedagogical work of Khrystyna Alchevska in the context of the adult education movement (On the 165 th anniversary of her birth)]. Istoryko-pedahohichnyi almanakh, (2), 65-72 [in Ukraina].

9. Vakhterova, E. (1912). Pyat'desyat let raboty dlya naroda: (k pyatidesyatiletnemu yubileyu Kh. D. Alchevskoy) [Fifty years of work for the people: (On the fiftieth anniversary of H. D. Alchevska)] Moskva: tip. P. P. Ryabushinskogo, 24 [in Russian].

10. Ivashchenko, V.\&Paliichuk, R. (2014). Pedahohichna diialnist Khrystyny Alchevskoi v dokumentakh iz fondu Derzhavnoi naukovo-pedahohichnoi

biblioteky

Ukrainy

imeni V.O. Sukhomlynskoho [Khrystyna Alchevska's pedagogical activities in documents from the collection of the V. Sukhomlinsky State Scientific and Pedagogical Library of Ukraine]. Visnyk knyzhkovoi palaty, (7), 39-42 [in Ukraina].

11. Korf, N. A. (1873). Nashe shkol'noe delo: sbornik statey po uchilishchevedeniyu [Our schoolwork:A collection of articles on school studies]. Moskva: izd. Brat'yev Salaevykh, 430 [in Russian].

12. Mazurkevich, A.R. (1988). Khristina Danilovna Alchevskaya [Khrystyna Danylivna Alchevska]. Antologiya pedagogicheskoy mysli Ukrainskoy SSSR / Sost. N.P.Kalenichenko. Moskva: Pedagogika, 255-258 [in Russian].

13. Mukhin, M.I. (1979). Pedahohichni pohliady $i$ osvitnia diialnist Kh.D. Alchevskoi [The pedagogical views and educational 
activities of H. D. Alchevska]. Kyiv: Vyshcha shkola, 183 [in Ukraina].

\section{АНОТАЦІЯ}

У статті висвітлено життєвий та творчий шлях Христини Данилівни Алчевської, зокрема, розглянуті основні напрями ї̈ просвітницької та педагогічної діяльності, а також науково-методичні здобутки в галузі педагогіки та вагомий внесок у розвиток украӥнської культури.

Зазначено, що Христина Алчевська однією з перших, в умовах заборони недільних шкіл, порушила питання загального безкоштовного початкового навчання, зокрема, навчальних закладів для жінок. Таким закладом стала Харківська недільна школа для жінок, що вісім років свого існування перебувала в нелегальному статусі.

Згідно принщипів різностороннього виховання та навчання Христина Алчевська у роботі Харківської недільної школи для жінок запровадила та популяризувала нові інновачійні форми та методи організачії навчально-виховного прочесу: бесіди про прочитане учнями, уроки на природi, розробки уроків письма, педагогічні збори, ведення щзоденника вчителями тощзо.

Свої педагогічні погляди та практичний досвід роботи Христина Алчевська представила у численних прачях. Серед них: «Передуманное и пережитое: дневники, письма, воспоминания» (1912), Полувековой юбилей» (1912) та інші.

Невід'ємну частину просвітницької діяльності Христини Алчевської посідає послідовна і иілеспрямована популяризація художньої літератури та культури читання загалом. 3 ијєю метою, иляхом кропіткої спільної прачі з вчителями та учнями, було створено показчик книг для народного й дитячого читання «Что читать народу?» (1884-1906) у трьох томах. Видання високо оиінили Л. Толстой, А. Чехов, І. Франко, Леся Украӥнка. 
Підсумки педагогічної роботи та запроваджених навчально-методичних інновачій Христина Алчевська неодноразово публікувала у вигляді річних звітів, щуо містили докладну інформацію про проблеми школи.

Одним з першочергових питань в організації навчальновиховного прочесу для Христини Алчевської був підбір викладацьких кадрів, використання ними передового педагогічного досвіду в роботі та схильність до постійного самовдосконалення. Серед вчителів-новаторів школи Христини Алчевської слід виокремити видатного украӥнського письменника Б. Грінченка, щзо викладав у земській школі с. Олексї̈вки на Катеринославщині фундаторами якої теж була родина Алчевських.

Христина Данилівна Алчевська, як і вся ї̈ родина, значною мірою вплинула на проиес еволющіï педагогічної думки та вітчизняної культури, піднявши ї̈ на високий щабель розвитку.

Ключові слова: Христина Алчевська, педагогіка, освіта, методика, недільна школа, педагогічна діяльність, педагогічний досвід, інновачїі.

\section{АННОТАЦИЯ}

B статье освещены жизненный и творческий путь Кристины Даниловны Алчевской, в частности, рассмотрень основные направления ее просветительской и педагогической деятельности, а также научно-методические достижения в области педагогики и выдающийся вклад в развитие украинской культуры.

Отмечено, что Кристина Алчевская одной из первых, в условиях запрета воскресных школ, поставила вопрос всеобщего бесплатного начального обучения, в частности, учебных заведений для женщин. Таким заведением стала Харьковская воскресная школа для женшчин, которая восемь лет своего существования находилась в нелегальном статусе.

Согласно приниипов разностороннего воспитания $и$ обучения Кристина Алчевская в работе Харьковской 
воскресной школы для женщин ввела и популяризировала новые инновационные формы и методы организации учебновоспитательного прочесса: беседы о прочитанном с учениками, уроки на природе, разработки уроков письма, педагогические собрания, ведение дневника учителями и тому подобное.

Свои педагогические взгляды и практический опыт работы Кристина Алчевская представила в многочисленных трудах. Среди них: «Передуманное и пережитое: дневники, письма, воспоминания» (1912), «Полувековой юбилей» (1912) и другие.

Неотьемлемую часть просветительской деятельности Кристинь Алчевской занимает последовательная $и$ целенаправленная популяризация художественной литературы и культуры чтения в целом. С этой цуелью, путем кропотливой совместной работы с учителями и учениками, был создан указатель книг для народного и детского чтения «Что читать народу?» (1884-1906) в трех томах. Издание высоко оценили Л. Толстой, А. Чехов, И. Франко, Леся Украинка.

Итоги педагогической работы и введенных учебнометодических инноваџий Кристина Алчевская неоднократно публиковала в виде годовых отчетов, содержащих подробную информацию о проблемах школьл.

Одним из первоочередных вопросов в организации учебновоспитательного процесса для Кристинь Алчевской был подбор преподавательских кадров, использования ими передового педагогического опыта в работе и склонность к постоянному самосовершенствованию. Среди учителейноваторов школь Кристинь Алчевской следует выделить выдающегося украинского писателя Б. Гринченко, преподававшего в земской школе с. Алексеевки на Екатеринославщине, учредителями которой тоже была семья Алчевских.

Кристина Даниловна Алчевская, как и вся ее семья, в 
значительной мере повлияла на процеесс эволючуии педагогической мысли и отечественной культуры, подняв ее на высокий уровень развития.

Ключевые слова: Кристина Алчевская, педагогика, образование, методика, воскресная школа, педагогическая деятельность, педагогический опьт, инновации. 